RESEARCH ARTICLE

\title{
"Not just a movement for famous white cisgendered women:" \#Me Too and intersectionality
}

\author{
Rosanna Maule* \\ "Mel Hoppenheim School of Cinema, Concordia University, Canada
}

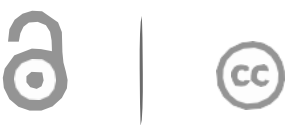

$\mathbf{6}$ Open Access

Citation: Maule, R. "Not just a movement for famous white cisgendered women:" \#Me Too and intersectionality. Gender and Women's Studies. 2020; 2(3):4.

Received: June 06, 2018 Accepted: February 13, 2020

Published: March 06, 2020

Copyright: @2020 Maule R. This is an open access article distributed under the terms of the Creative Commons Attribution License, which permits unrestricted use, distribution, and reproduction in any medium, provided the original author and source are credited.

\section{Corresponding author:}

Rosanna Maule, Mel Hoppenheim School of Cinema, Concordia University, Canada.

E-mail: rosanna.maule@concordia.ca

\begin{abstract}
The civil rights activist Tarana Burke founded 'me too.' in 2006 to help survivors of sexual abuse over-coming their trauma through the force of empathy and communitybased support (https://metoomvmt.org/about/\#history). The movement kept a rather discrete profile until 2017, when the actress Alyssa Milano - prompted by the revelations of Harvey Weinstein's sexual misconduct - posted a Tweet to invite women who had been victims of sexual harassment to respond using the expression "me too" (Milano, 2017). The hashtag \#Me Too became immediately viral, triggering a worldwide mobilization on social media and in the public sphere (Hosterman, Johnson, Stouffer \& Herring, 2018).

While the transition from grassroots initiative to global phenomenon of empathic solidarity among survivors of sexual violence has given the movement momentum and visibility, it has also raised multiple critiques and debates. Media commentators, activists, and scholars have especially blamed the marginalization of women of color within the post-hashtag phase of the movement and its 2017-2018 whitewashing campaign led by prominent Hollywood stars (Garcia, 2018; Gieseler, 2019; McCartney, 2018; Ohlheseiser, 2017; Onwuachi-Willig, 2018; Scott, 2017).

This essay examines the post-2017 unfolding of \#Me Too from an intersectional perspective, situating it within the history of U.S. Black Feminism and feminist fourthwave feminist activism. The argument is that Burke's movement has maintained its inclusionary mission, in spite of the mainstream trends it has undergone since its shift to social media and transformation into a transnational movement of protest. Drawing on critical race feminist theory, intersectional feminist theory, and feminist approaches to new media, this paper proposes that in its latest iteration on digital and social platforms \#Me Too has amplified Burke's strategy of resilience through transformative empathy, reaching vaster and diversified communities of survivors.
\end{abstract}

\section{Keywords}

Feminist media organizations; intersectionality; gendered mobilization; affective participation; fourth wave feminism

\section{Introduction}

"The only narrative should start and end with survivors. Period". 
This peremptory statement - included in an interview with the trade magazine Variety in April 2018 - synthesizes Tarana Burke's stance vis-à-vis the criticism surrounding a movement that she founded in 2006 to help women of color living in marginal communities within the US overcoming the trauma of sexual violence (ibid). The debate especially focused on the glamour-filled, whitewashing campaign against sexual harassment endorsed by Hollywood stars and high-profiled personalities within the US (ibid). In her response to Variety, Burke stressed the movement's inclusionary vocation (ibid), a position that she has since always maintained. In November 2017, Burke published an article in The Washington Post, eloquently entitled "\#MeToo Was Started for Black and Brown Women and Girls. They're Still Being Ignored," in which she specifies that the narratives of \#Me Too are "those of people of color, queer people, disabled people, poor people" (Burke, 2017). A few months later, she addressed an audience of graduate students at Cornell University, stating: "\#Me Too is not just a movement for famous white cisgendered women. What we are is a global community of survivors committed to healing as individuals and as a community" (Cook, 2018). ${ }^{i}$

While careful to keep the intersectional mandate at the centre of the movement, Burke has also welcomed the public visibility and the new potential that social media and digital platforms assure to it, opening up the dialogue to vast and diversified platforms of survivors. ${ }^{\text {ii }}$

Focusing on Burke's approach to sexual violence, this essay aims to demonstrate that \#Me Too has maintained its inclusionary vocation, in spite of the mainstream publicity to which it has been exposed, as well as of the limitations and potential risks it has undertaken since its development into a global movement of protest (Cobb \& Horeck, 2018; Gill \& Orgad, 2018; Mendes, Ringrose \& Keller, 2018). From this perspective, my argument is that \#Me Too's position is coherent with that of Black Feminism, as Duchesse Harris defines it in her book "Black Feminist Politics from Kennedy to Trump" : it "is intersectional, considers issues of power, access, and disenfranchisement in nuanced, layered ways, and ultimately offers a higher bar to which to hold US politics"(2019 12).

At the international level, \#Me Too's commitment to intersectionality rests on its adoption of transversal and egalitarian forms of embodied action, in the sense that Judith Butler, in her article "Performative Acts and Gender Constitution: An Essay in Phenomenology and Feminist Theory," gives to "acts by which gender is constituted bear similarities to performative acts within theatrical contexts" (Butler, 1997: 403). \#Me Too is also a new instance of what Butler, in her 2015 book Notes Toward a Performative Theory of Assembly, identifies as actions that point at a shared and unjust social conditions (Butler, 2015: 15-16). This new type of performative act, argues Butler, "enacts a provisional and plural form of coexistence that constitutes a distinct and social alternative to 'responsibilization"' (ibid). According to Butler, embodied action is " a form of action that demands the conditions for acting and living" in the form of performative assembly, that is, as a "nascent and provisional versions of popular sovereignty"(ibid). Following Butler, I suggest that especially since its revamp as a viral hashtag in 2017, \#Me Too has become a global phenomenon of performative assembly for communities of survivors from sexually related assault.

Drawing on a theoretical framework including critical race feminist theory, intersectional feminist theory, and feminist approaches to new media, this essay will first situate \#Me Too within the context of U.S. Black Feminism, explaining the central role of intersectionality within this area of the U.S. Women's Movement. The second part of the article will trace the trajectory of \#MeToo since 2017, arguing that the consistency of the intersectional focus within the movement rests in its transformation into a global form of feminist solidarity as embodied action. As such, \#Me Too keeps spreading collective consciousness and discussion about the articulation of gender, class, race, and sexuality in the US and internationally. The overall argument is that \#Me Too has expanded to global scale activism while maintaining its inclusive mandate.

Central questions in my analysis will be: How has intersectionality informed the movement over the years? What strategies does the movement implement "to sustain long term, systemic healing and change" in a global conversation about sexual violence (https://metoomvmt.org/about/\#history)? 


\section{The Power of Empathy: \#MeToo and Feminist Solidarity}

Tarana Burke, a native of New York, created "me too" in 2006 as one of the programs of Just Be Inc., a "youth organization focused on the health, well-being and wholeness of young women of color" (https://justbeinc.wixsite.com/justbeinc/purpose-mission-and-vision), As Burke herself explains, the inspiration for her initiative was her experience as a survivor of rape and as a counsellor at a youth camp where she worked in the late 1990s while she was living in Selma, Alabama, soon after graduating from Alabama State University" (ibid). In particular, the expression "me too" and the central concept in the movement ("empowerment through empathy") stem from an episode that marked Burke's formation as a social worker, reported on the me too.'s website whose link is available on the Just Be Inc website (https://metoomvmt.org/the-inception/; https://justbeinc.wixsite.com/justbeinc/the-me-toomovement-cmml). The event refers to Burke's inability to help a young girl victim of sexual violence, because her story was too close to hers (ibid). Burke's personal testimony is used as a narrative to explain the movement's approach to healing through empathy, to which Burke often refers in terms of a transformative and empowering force among survivors of sexual violence.iii

Michelle Rodino-Colocino, in the article "Me too, \#MeToo: countering cruelty with empathy," underscores the uniqueness of this concept, as it brings together transformation, solidarity, and advocacy (2018: 96). As Rodino-Colocino explains, empathy has often had negative connotations within critical and cultural studies, especially when associated with passivity, sociocultural difference, and the activation of unequal and ultimately oppressive forms of response to "shared feelings and experiences" on social media (ibid). . Burke's idea of empathy is instead based on egalitarian relations and is a source of action: it is "an agent for exposing systems of oppression and privilege of which sexual harassment and assault are cause and effect" (Rodino-Colocino, 2018: 97). This type of empathy leads to "transformative justice" and facilitates victims of sexual violence - especially those coming from marginalized communities - overcome feelings of isolation, shame, and blame (ibid). Rodino-Colocino's overall argument is that empathy "fuels \#Me Too past its hashtag moment to pierce Trump's cruelty and come out the other side of-and indeed outlast-his presidency without losing momentum" (2018: 99).

\#Me Too has arguably marked a turning point in U.S. culture, particularly in the politically charged climate of the post-Trump election, as well as of the Weinstein case and many more Hollywood-related instances of sexual assault trials and allegations. Furthermore, the movement has fostered public denunciation and social awareness about sexual violence both at the national and at the international levels, including geocultural and political areas where dealing with sexual harassment in public and in legal arenas is especially difficult for gendered minorities (Onwuachi-Willing, 2018: 119).

Two months after the launch of the hashtag \#Me Too, the Time magazine paid homage to the movement through a double issue that named 'person of the year' the so called "Silence Breakers" (Zacharek, Dockterman \& Sweetland, 2017). Regarding the criteria that had led to choose a dozen of testimonies out of the thousands who had joined \#MeToo, the issue's co-editors explained that they wanted to cover "all races, all income classes, all occupations and virtually all corners of the globe" (ibid). Correctly pointing out the sociocultural, class, racial, and religious differences that separated the women featured in their cover story, the journalists insisted on the fact that what brought these women together was their shared experience (ibid). Following the same rationale, the magazine's cover page strategically featured some celebrities alongside with anonymous women. Two Hollywood and music stars (Ashley Judd and Taylor Swift, respectively), were photographed side by side with three unknown women from different backgrounds: a Latino strawberry picker from Mexico; a white Uber engineer from Texas; and an African-American corporate layer from Sacramento (ibid). The magazine's purpose in celebrating \#MeToo as a global, inclusive movement was to transcend its preeminent association with white media celebrities, showing how the movement was instead reaching out to different classes and ecocultural areas around the world. Some of the testimonies included in the magazine were by women 
originating from countries where women's rights are still in progress or not acknowledged, such as, for instance, Afghanistan and Iran (ibid).

Many feminist scholars specialized in digital feminist activism consider \#Me Too as one of the most significant examples of gender-specific solidarity, even though they acknowledge the difficulties in gauging the movement's actual impact. As Kaitleen Mendes, Jessica Ringrose, and Jessalynn Keller point out in "\#MeToo and the promise and pitfalls of challenging rape culture through digital feminist activism," "While hashtag feminism has received substantial attention from mainstream media, we still know very little about what hashtags like \#MeToo actually do; or whether and how they can produce social change" (2018: 237). Other scholars working in this area point at the limits and the nuances of the movement within the framework of recurring patterns and trends in feminist activism on digital platforms and social networks (Cobb and Horeck 2018; Gieseler 2019; Mendes, Ringrose \& Keller, 2018).

In spite of the inseparable connection between the constitutively inclusive intersectionality of U.S. Black feminism and the role of empathic solidarity in \#Me Too, the vast and rapid escalation of the movement to a global phenomenon with high media exposure has brought disparate contexts and actors into play, pushing Burke to foreground diversity as a priority. More recently, Burke has denounced the still predominant marginalization of gendered minorities in the media in a day-long streaming event organized by the Time magazine on April $23^{\text {rd }} 2019$ in which she was featured as one of the year's 100 most influential people. On that occasion, she said: "The women of color, trans women, queer people-our stories get pushed aside and our pain is never prioritized. We don't talk about indigenous women. Their stories go untold" (Chan, 2019).

\#Me Too's exposure to whitewashing trends in US feminist and digital culture began with the creation of the hashtag: Alyssa Milano, in the Tweet that she posted on October $15^{\text {th }}$ 2017, notoriously referenced the expression "me too" to an anonymous friend, omitting to mention Tarana Burke as the movement's founder (Milano, 2017). ${ }^{\vee}$ The controversy about this problematic omission immediately circulated on social media (Ohlheiser, 2017). Only two days after the Time's special issue about the "Silence Breakers," The Washington Post denounced the racially discriminatory tendencies of the movement in an article entitled "The marginalized voices of the \# \#MeToo movement" (Scott, 2017), specifying:

She [Burke] didn't start the \#MeToo movement for affluent and powerful white women on Capitol Hill and in Hollywood whose voices often have the most influence. Burke sought to draw attention to the pervasiveness of sexual assault in all racial, cultural and socioeconomic backgrounds (ibid).

Even though Burke was promptly integrated into the \#MeToo campaign and attended many high-profiled Hollywood events to advance the movement's unitary cause, the criticism continued. In November 2017 the freelance journalist and artist Jordannah Elizabeth talked about this issue quoting a comment that Jane Fonda had made during the star's participation in a TV program (Elizabeth, 2017). On that occasion, Fonda stated:

It's too bad that it's probably because so many of the women that were assaulted by Harvey Weinstein are famous and white and everybody knows them. This has been going on a long time to black women and other women of color and doesn't get out quite the same" (Elizabeth, 2017).

Gabrielle Union addressed the problem of discrimination within the Hollywood-related development of the movement in an interview with The New York Times in December 2017 (Butler, 2017). Reminding that she had been complaining about sexual harassment since 2001, Union asked 'If those people hadn't been Hollywood royalty, if they hadn't been approachable. If they hadn't been people who have had access to parts and roles and true inclusion in Hollywood, would we have believed?" (Butler, 2017). A blatant instance of racial discrimination in the Hollywood-related \#Me Too campaign concerns Weinstein's different response to accusations against him made by women of color (Garber, 2017; White, 2017; Oldham, 2018). One of the earliest examples was that of the Kenyan-Mexican actress Lupita Nyong'o, who in October $19^{\text {th }} 2017$ revealed to have been harassed by Weinstein on several occasions in an op-ed for The New York Times (Nyong'o, 2017). Weinstein - who had kept relatively silent about the many allegations that were being made against him — publicly discredited her accusations (Wang 2017). Two months later, Weinstein equally dismissed the 
accusations of the Mexican actress Salma Hayek (Moniuzska, 2017), who, like Nyong'o, had written an article for the New York Times about her longtime experience of harassment by the mogul (Hayek, 2017). Another widely discussed case was that of Lena Dunham and Jenny Konner's defence of Murray Miller, accused of having harrassed Aurora Perrineau while she was under age. The action generated a massive outcry, prompting Dunham to write an apology statement (White, 2017). Tarana Burke was among those who reacted to the debate, in a Tweet in which she compared Perrineau's to Nyong'o unfair treatment:

People are saying why I keep saying 'marginalized voices need to be centred' @leanadhunam is the reason why. Maybe I should be more clear: BELIEVE BLACK WOMEN. Both Dunham's Statement and apology are trash (2017)

In response to these critiques, Hollywood actresses brought intersectionality into play in the discussion of sexual violence. Laverne Cox was one of the first ones to use the term in an interview with The Hollywood Reporter, in which she commented: "I think we can always be more intersectional. We can always include more people. I don't just experience the world as a trans woman. I experience the world as a black person. I have multiple identities" (Perez, 2017). Tarana Burke made a very significant public appearance at the 2018 Golden Globes, speaking alongside Michelle Williams. At the 2018 Oscar ceremony - reporters celebrated the intervention of Ashley Judd, Annabella Sciorra, and Salma Hayek - three of Weinstein accusers - as an "intersectional moment" (Saad, 2018). At the same ceremony, Frances McDormand made a nuanced hint to intersectionality during her acceptance speech, making reference to the "inclusion rider," a provision that the media deciphered as a contractual request whereby a star may impose diversity within the cast (Ross, 2018). ${ }^{\mathrm{vi}}$

Yet how could intersectionality be addressed in a movement simultaneously accused of racial marginalization? Angela Onwuachi Willig, in the article "What About \#UsToo?: The Invisibility of Race in the \#MeToo Movement," accuses \#Me Too "for both initially ignoring the role that a woman of color played in founding the movement ten years earlier and in failing to recognize the unique forms of harassment and the heightened vulnerability to harassment that women of color frequently face in the workplace" (2018: 105). According to Onwuachi Willig, \#Me Too "reflects the longstanding marginalization and exclusion that women of color experience within the larger feminist movement in U.S. society" (2018: 107). The next section will try to answer this question by placing Burke's movement within the context of US feminism and its divided history alongside racial discourse.

\section{\# Me too and the Legacy of Discrimination in the U.S.}

Beside repeating mainstreaming patterns in feminist digital activism and hashtag feminism (Gieseler 2019; Gill and Orgad 2018; Mendes, Ringrose, and Keller 2018), the marginalization of women of color within \#Me Too goes back to a long trail of racist patterns within U.S. social and feminist movements (Gieseler, 2019: 27-69; Onwachi-Willing, 2018). Carly Gieseler, in her book The Voices of \#MeToo: From Grassroots Activism to a Viral Roar, situates the whitewashing phenomena intrinsic in the post-2017 iteration of \#Me Too within this lineage (2019: 27-29). From this perspective, she considers Burke's community-based movement within the obscured lineage of Anita Hill and many other Black women that have sustained gendered violence in public within the U.S. as a form of racial opposition (Gieseler 2019: 48-49). Gieseler argues that the development of \#Me Too as a popular hashtag has contributed to suppress knowledge about the movement's intersectional history and purpose (Gieseler 2019: 52). This is why, Gieseler concludes, "Intersectional approaches are relevant in considering not only the internal experiences and expectations of individual women but also the external oppressions of race, sexuality, class, and myriad of other sociopolitical systems" (Gieseler 2019: 49). This framework of analysis, as I will further opine in this paper, highlights not only the intersectional genealogy of \#Me Too, but also its consistent commitment to inclusionary politics within the US and in the global sphere. Gieseler, in her above-mentioned book, recognizes the challenges that the 'multidimensional factors of oppression against race, sexual orientation, gendered identity, religious affiliation, political allegiance, and continually expanding aspects of identity" pose to \#Me Too (2019: 49). Gieseler applies this general tendency to social justice campaigns, which "are sustained or generated from shared narrative or mutual recognition - rather than individual difference ...[and] have often appropriated, mutated or silenced these perspectives (2019: 50). 
Speaking about this problem, Angela Onwuachi-Willig explains that in \#Me Too "the realities of white women's lives, as opposed to the distinctive harassement employed against black women and other women of color, still define the female experience" (2018: 119).

The racial bias denounced within \#Me Too after 2017 finds origin in U.S. society and its long history of ideological divisions across racial lines, also within the context of the Women's Movement. Scholars of various ethnic backgrounds and theoretical formations have addressed this schism. Blanche Radford Curry gives her contribution to the 1995 collection Overcoming Racism and Sexism, co-edited by Linda A. Bell and David Blumenfield with an essay entitled "Racism and Sexism: Twenty-First Century Challenges for Feminists" (Radford Curry 1995). Radford Curry calls for solidarity between White feminists and Black feminists, yet in doing so she gives three recommendations: to highlight African American women's distinctive standpoint; to appreciate the difference in their sociocultural oppression; and to stop giving prominence to sexism over racism (Radford Curry 1995: 20-27).

More than two decades later, Winifred Breines, in The Trouble Between Us: An Uneasy History of White and Black Women in the Feminist Movement, inquires into the gap between Black and White feminism from the viewpoint of a White activist "disturbed by the charge, found repeatedly in writings on second wave feminism, that the white women's movement was racist" (2006: 7). Her purpose is to consider the reasons that have impeded a "racially integrated women's liberation movement develop in the United States" (Breines 2006: 6). Leaving behind subjective positions to instead root her argument on archival research at feminist groups, organizations, and projects from both Black and White circles, Breines comes to acknowledge the existence of unconscious racism, as well as of skepticism among radical activists regarding nostalgic notions of community in a political system that overlooks "equality, justice, freedom, or community" (Breines 2006: 1-14). She concludes that, by the end of the 1970s "the radical women's movement came full circle, from a goal of integration to a politics of separation to tentative efforts to reconnect" (2006:17). Finally, Jo Reger, in an anthology of essays on community-based feminist activism entitled Everywhere and Nowhere: Contemporary Feminism in the United States, considers inclusivity the major concern within the Women's Movement since the 1980s (2012). In her book, Reger underlines the "continuing need for U.S feminism to acknowledge and address issues of racism, privilege, diversity, and inclusivity" (2012: 132).

"The racial divide" within the Women's Movement reflects the oppression of Black women and women of color within U.S. society and worldwide and justifies Black feminism's distinctive trajectory within the Women's Movement. Patricia Hill Collins, in Black Feminist Thought: Knowledge, Consciousness, and the Politics of Empowerment (2000), identifies the distinctiveness of Black Feminism in its formation as a social theory of empowerment, in reaction to the historical erasure and oppression of Black women in US society (Hill Collins, 2002). For Hill Collins, the erasure of Black women from US society is due to three sets of interrelated circumstances: labor exploitation; political exclusion from vote and from public office; and ideological control through stereotyping (2002: 4-5). To these, Hill Collins adds a more recent form of depoliticization of Black Feminism, rooted in U.S. postmodern education and in its occult and marginal status within White Feminism (Hill Collins 2000: 5-6). According to Hill Collins, Black Feminism is a critical social theory: as such, it "encompasses bodies of knowledge and sets of institutional practice that actively grapple wit the central question facing U.S. Black women as a collectivity (Hill Collins 7-9).

Commenting on the politics of exclusion of Black women within the U.S., bell hooks prefaces the second edition of Ain't I A Woman?Black Women and Feminism - first published in 1981- with her own memory about experiencing a lack of place as a young Black female in the liberation movement (2015: ix-x). ${ }^{\text {vii }}$ In the same section of her book, hooks talks about White Feminists' unconscious complicity with racist-sexist attitudes through their adoption of oppression as a freeing position (2015: 8-9). Duchesse Harris, in her aforementioned book on Black Feminism, brings forward the importance of groups from the class-privileged Presidential Commission on the Status of Women (PCSW) active under the Kennedy administration to the grassroots radical movements of the 1970s. Among other, she stresses the National Black Feminist Organization (NFBO), established in Durham in 1973 and active until 1976 and the lesbian-radical organization Combahee River Organization (CRO), founded in Boston in 1974 and active until 1980. Harris argues that these groups "all 
strategically deprioritized gender depending on available openings in the social movement and political opportunity structures" (Harris 2002: 7-12). viii

Intersectionality has been at the centre of Black Feminism discourse since the 1980s. An interdisciplinary approach drawing on Critical Race Theory and Feminist Studies, the concept is based on a Law-informed reading of the sociopolitical and institutional implications of gendered oppression such as race, class, gender, and sexuality. The Law and Critical Race scholar Kimberlé Crenshaw first used this term in an article entitled "Demarginalizing the Intersection of Race and Sex: A Black Feminist Critique of Antidiscrimination Doctrine, Feminist Theory, and Antiracist Politics" (1989). According to Crenshaw, the purpose of intersectionality is "to address the marginalization of Black women within not only antidiscrimination law but also in feminist and antiracist theory and politics" (Crenshaw 1989). Intersectionality involves theorizing discrimination against Black women from a variety of perspectives. As Crenshaw explains, "this single-axis framework erases Black women in the conceptualization, identification and remediation of race and sex discrimination by limiting inquiry to the experiences of otherwise-privileged members of the group (ibid).

In 2013, a group of interdisciplinary scholars from UCLA, including Devon A. Carbado, Kimberlé W. Crenshaw, Vickie M. May, and Barbara Tomlinson have edited a special issue of $\mathrm{Du}$ Bois Review revisiting intersectionality in light of today's politics (2013). In their introduction, the co-editors, after defining the term "a method and a disposition, a heuristic and analytic tool," highlight four of the characteristics of intersectionality: its being "in progress;" its equally shared interdisciplinarity; its redeployment of the global dimensions of history and power; and its application to the social (ibid). Manouchecka Celeste, in her contribution to a recent special issue of Feminist Media Histories dedicated to genealogies entitled "Black Feminist Studies," argues "For Black feminist media scholars, intersectionality is not a buzzword but a central analytic for articulating our experiences and representations as multiply oppressed. Feminism in Black media studies claims that Black women matter, are subjects, have agency, and are to be taken seriously"(2018: 38-39).

The concept of intersectionality inspires Burke to found 'me.too' as a movement of solidarity aimed at empowering "young Black women and girls from low wealth communities ...through empathy and community-based action" (https://metoomvmt.org/about/\#history). Carly Gieseler, in her aforementioned study, suggests that the movement uses "intersectional experiences as sources of empowerment and resistance against oppressive and abusive forces" (Gieseler, 2019: 3). Yet, as Myra Marx Ferree argues in her article "Inequality, intersectionality, and the politics of discourse,"intersectionality ...cannot be located at any one level of analysis, whether individual or institutional ... but a process through which race takes on a multiple 'gendered' meanings for particular women and men" (2018: 85). ${ }^{i x}$ As the next sections will illustrate, this process has informed \#Me Too's approach to inclusion from community-centred initiatives to global phenomena of mass mobilization.

\section{me too. and Black American Feminism}

Within the US, U.S. Black social activism and particularly Black Feminism's intersectional response to gendered violence and understanding of the interrelation of gender, race, and class in cases of rape and harassment are the inspirational sources of \#Me Too's grassroots response to sexual violence. Burke's profile as a civil rights activist and an advocate for the elevation of minority women within the US situates \#Me Too within this lineage (https://metoomvmt.org/the-inception/). As mentioned above, Burke founded me too. as one of the programs associated with Just Be Inc., a non-profit organization to advance young women of color. Burke is still the director of that organization and a member of the board of directors, which includes African-American scholars, intellectuals, educators, artists, educators, and activists, all women but one (https://justbeinc.wixsite.com/justbeinc/board). Just Be Inc. offers customized workshops for girls attending schools in the Philadelphia area (where the organization was founded), as well as in New York and in Alabama (https://justbeinc.wixsite.com/justbeinc/workshops-and-trainings). These workshops address issues of racial and ethnic identity and include a workshop about sexual violence based on 
the experience of the movement, entitled "me too: Exploring sexual abuse, assault and exploitation in our community" (ibid). The other program offered by the organization is Jewels, an educational trajectory "designed for girls between 12 and 18 years old" attending affiliated schools located in the Philadelphia area, as well at the ARISE Academy in New Orleans https://justbeinc.wixsite.com/justbeinc/programs).

The links of Burke's movement with this area of social activism are evident in the movement's organization, which relies on an established network of community centres, domestic shelters, violence crisis centres, and neighbourhood associations. The movement has posted these resources on its digital platform, the me too.org, launched in 2018, which contains detailed information for survivors of sexual violence (https://metoomvmt.org). In association with the non-profit organization Girls for Gender Equity (GGE), the movement has been documenting its work on this platform. ${ }^{\times}$Building on the popularity of the hashtag, the movement's official website has been posting testimonies by survivors, articles about the movement, a press area with Burke's public interest announcements, interviews with Burke, and news about Burke's public lectures and talks, as well as participation in various types of public events, from glamorous Hollywood award ceremonies to mass protests and rallies. ${ }^{\text {i }}$

A section of the movement's website is especially dedicated to people of color and contains information about institutions for legal support (e.g. The Women Lawyers Division of the National Bar Association), non-profit organizations for minority women such as the National Indigenous Women's Resource Center, the Mending The Sacred Hoop, the Asian Pacific Institute on Gender Based Violence (APIGBV), and community centres such as the Casa de Esperanza for Latino Women (https://metoomvmt.org/advocacy-resourceslibrary/national-resources/). Beside referring to institutions for counselling, legal support, and accommodation, this section of the platform provides references for interest groups and associations, such as, for instance, The National Organization of Sisters of Color Ending Sexual Assault, the radical feminist organization for women of color Incite!, and the association for women incarcerated Just Detention International (JDI) and Justice Now. The movement, in association with the Girls for Gender Equity (GGE) international organization, has developed a special program for young women registered in the Historically Black Colleges \& Universities (HBCUs), a lecture series tour in which Burke is personally involved that offers on-campus workshops regarding sexual violence. ${ }^{\text {xii }}$ The program takes inspiration from the GGE's mission, which is "to eliminate gender-based violence within school systems" and is based on Title $\mathrm{XI}$ of the civil rights law requiring that any educational institution receives government funds to assure equal opportunities to all students, regardless of gender (https://www.ggenyc.org/about/education/).

\section{\# Me too and the Imagined Body Politics of Feminist Digital Activism}

Since the first decade of the new millennium, two distinctive albeit interrelated circumstances have contributed to the possibility for phenomena like the \#MeToo hashtag to emerge: firstly, the revival of the popular assembly as a form of political gesture within and throughout geocultural contexts around the world; secondly, the rise of digital media tools allowing embodied forms of collective participation. The emergence of \#MeToo as a global movement exemplifies a type of social action that Judith Butler, in the above-mentioned Notes Toward a Performative Theory of Assembly, describes as a performative enactment of radical democracy via new media (2015: 7-8). According to Butler, these types of movements are transitory, self-determined social actions, embodied and performed through various forms of collective gathering, including virtual or digital networks (2015).

\#Me Too may be considered a particular variant of Butler's idea of collective assembly, as a social action taking place in conditions of precarity (Butler 2015: 23). The collective action resulting from precarity produces a type of social solidarity that Butler defines "both mournful and joyful, a gathering enacted by bodies under duress or in the name of duress, where the gathering itself signifies persistence and resistance" (Butler 2015: 23). An important aspect of these new forms of collective action is their dependance on infrastructures and media that assure an enduring and collective performativity (Butler 2015: 21). In the second chapter of the book, Butler considers the association of precarity and 
gender norms, which implies the risk of "harassement, pathologization, and violence," as well as the sexual politics associated with discrimination against certain gender norms or sexual practices" (Butler, 2015: 34).

In examining the link between performativity and precarity with regard to gender, she suggests that embodied forms of collective action imply both a field of appearance and a scheme of recognizability for performativity (2015: 38-39). An important aspect of the political performativity of gender and the conditions for its political action is the sphere within which it can be safely appear and be acknowledged (ibid). For Butler, the "right to appear" is a "coalitional framework" that links together "performativity" and "precarity" (ibid). Butler refers to collective gendered embodiment negotiating gender and performance as "the paradox of plural performative action under condition of precarity" (Butler 2015: 50). As a form of embodied action, \#MeToo brings together communities of survivors that enact gender and performativity into a bodily action under the precarious condition of sexual trauma (e.g., the "Silence Breakers" that self-determine themselves through the participation in the movement). \#Me Too has made visible and circulated the testimonies of survivors, silenced or isolated because of sociocultural conventions and power systems.

By the same token, \#MeToo is an instance of what Prudence Chamberlain, in her book The Feminist Fourth Wave: Affective Temporality, presents as the conjuncture of a new surge of women's social activism, characterized by the use of social media and affective intensity (2017). xiii Weaving together feminism, feeling, and social movements through technologically achieved temporal intensity, Fourth Wave feminism breaks away from the generational confrontations and the hierarchical distinctions of the previous waves. Instead, the members of this generation of feminism are "associated with the socio-political and technological contexts in which they arise, each one can be positioned as an affective temporality" (Chamberlain 2017: 460).

Chamberlain concludes that within Fourth Wave feminism,

Technology, such as Twitter and Facebook, has changed the ways in which feminists can communicate with one another. Both social media websites allow for activism to be organized rapidly and efficiently without feminists being required to occupy the same physical space as one another (2017: 462). ${ }^{\text {xiv }}$

The sudden propulsion of \#Me Too to global movement exemplifies both the vast opportunities that the public digital sphere may offer to women and feminist discourse and the problems that arise from them. Feminist scholarship has been investigating women's online movements for some years now. Kaitleen Mendes, Jessica Ringrose, and Jessalynn Keller, in their aforementioned article, consider \# Me Too " perhaps one of the most highprofile examples of digital feminist activism" within network culture (2018). Catherine MacKinnon, in a recent article entitled "Where \#MeToo Came From, and Where It's Going: The movement is moving the culture beneath the law of sexual abuse," reminds us that \#Me Too is built on decades of "collective work against sexual abuse ... including the professor Anita Hill's foundational testimony in 1991 that Clarence Thomas, nominated and also confirmed to the Supreme Court, had sexually harassed her years before"(2019). Reflecting on the social impact of \#Me Too, she underlines the two preconditions for the movement are the sexual harassement law and the 2016 Presidential election (ibid). According to MacKinnon, the law that exposes sexual harassement has been "a vector and dynamic of sex inequality based on gender with major white racist and class-based dimensions" (ibid). The contribution of the \#Me Too movement to a legal system that still encounters social prejudice and power inequality is the strategy of speaking out, which, as MacKinnon puts it, "has begun to erode the two biggest barriers to ending all forms of sexual abuse in law and in life: the disbelief and the trivializing dehumanization of victims" (ibid).

Rosalind Gill and Shani Orgad, in "The Amazing Bounce-Backable Woman: Resilience and the Psychological Turn in Neoliberalism," consider the post-2017 transformation of \#Me Too from yet another viewpoint (2018). Their purpose is to examine the scholarly field of gender, sexuality, and intimacy in the media and in popular culture at a moment when feminist and queer activism on social media raises questions about practices of solidarity (Gill and Orgad 2018: 477). Gill and Orgad "see the promotion of resilience part of an increasingly psychological turn within neoliberalism (2018: 478). In the case of \#Me Too, Gill and Orgad argue that the movement marks a shift of concern from sexualization to the 
intersection of sexuality and power, especially after "the intensifying incorporation of media and especially social media into intimate lives in popular movements" (2018: 480). ${ }^{x v}$

Hester Baer, in "Redoing feminism: digital activism, body politics, and neoliberalism," suggests that a strategy to set apart feminist solidarity within what she calls "the toxic environment of in online spaces of "neoliberal subjectivities" is "outlining the stakes of their body politics in this context" (2016:18). In the case of \#MeToo, this means recognizing the hashtag as a spontaneous, intersectional form of affective participation among survivors of rape, sexual harassment, gender discrimination, and exploitation from all over the world. Simultaneously, as many scholars acknowledge, we need to remain cautious and ambivalent about the changes and the discourse brought up by \#Me Too (Cobb and Horeck, 2018; Gill and Orgad, 2018). In terms of inclusivity, many questions remain about the actual possibility for all women to make a difference within the digital space (Mendes, Ringrose, Keller, 2018). If the focus remains on the survivors, we need to ask ourselves whose stories are told, within what contexts, what power structures and relations do these narratives partake in, and what communities of survivors are they part of. The narrative that Burke had in mind when she founded me too. was not one of privilege.

The emergence of the \#MeToo hashtag in 2017 has marked less a split than a progressive expansion of the movement that Tarana Burke founded in 2006 into different directions. As explained in the history section of the movement's website, the post-2017 phase of the movement has contributed "to reframe and expand the global conversation around sexual violence to speak to the needs of a broader spectrum of survivors. Young people, queer, trans, and disabled folks, Black women and girls, and all communities of color" (https://metoomvmt.org/about/\#history). In spite of the Hollywood and media campaign to which it has been exposed, the movement has maintained its inclusionary mission and remains a model of intersectional solidarity, open to a global and diversified community of survivors. The movement's potential rests in its possibility to create resilience through solidarity and affective participation, collectively responding to sexual harassment, gender discrimination, and exploitation.

\section{References}

Baer, H. (2016). "Redoing feminism: Digital activism, body politics, and neoliberalism." Feminist Media Studies 16(1), pp. 17-34.

Belam, M., \& Levin, S. (2018). "Woman behind 'inclusion rider' explains Frances McDormand's Oscar speech." The Guardian (March 2018),

Retrieved from: https://www.theguardian.com/film/2018/mar/05/what-is-an-inclusion-rider-francesmcdormand-oscars-.

Bell, L. A., \& Blumenfeld, D. eds. (1995). Overcoming Racism and Sexism. Boston: Rowan \& Littlefield.

Breines, W. (2006). The Trouble Between Us: An Uneasy History of White and Black Women in the Feminist Movement. Oxford: Oxford University Press.

Burke, T. (2017). "\#MeToo Was Started for Black and Brown Women and Girls. They'Re Still Being Ignored." The Washington Post November.

Retrieved from: https://www.washingtonpost.com/news/post-nation/wp/2017/11/09/the-waitress-whoworks-in-the-diner-needs-to-know-that-the-issue-of-sexual-harassment-is-about-her-too/?noredirect=0.

-2017 Twitter @TaranaBurke, October 25.

Butler, B. B. (2017). “Gabrielle Union on \#MeToo: 'The floodgates have opened for white women' The Washington Post December 8.

Butler, J. (2015). Notes Toward a Performative Theory of Assembly. Cambridge, MS: Harvard University Press.

-1997 "Performative Acts and Gender Constitution: An Essay in Phenomenology and Feminist Theory." Writing on the Body: Female Embodiment and Feminist Theory Eds. Conboy, Katie, Nadia Medina, and Sarah Stanbury; Columbia University Press, pp.401-418.

Carbado, D. W. C., Williams, K. C., Mays, V. M., \& Tomlison, B. eds. (2013). Intersectionality: Mapping the Movements of a Theory Du Bois Review, 10(2), pp. 303-312.

Retrieved from: https://www.cambridge.org/core/terms. https://doi.org/10.1017 S1742058X13000349. 
Chamberlain, P. (2017). The Feminist Fourth Wave: Affective Temporality, Palgrave Macmillan, London,

-2016 "Affective temporality: towards a fourth wave." Gender and Education, 28(3), pp. 458-464, http://dx.doi.org/10.1080/09540253.2016.1169249.

Chan, M. (2019) "Our Pain Is Never Prioritized.' \#MeToo Founder Tarana Burke Says We Must Listen to 'Untold' Stories of Minority Women." Time (April 23).

Retrieved from: https://time.com/5574163/tarana-burke-metoo-time-100-summit/.

Cook, B. (2018). "MeToo founder discusses intersectionality and activism." The Ithacan, February 6. Retrieved from: https://theithacan.org/news/metoo-founder-discusses-intersectionality-and-activism/

Crenshaw, K. (1989). "Demarginalizing the Intersection of Race and Sex: A Black Feminist Critique of Antidiscrimination Doctrine. Feminist Theory, and Antiractist Politics." University of Chicago Legal Forum, 1(1); Article 8. Retrieved from: http://chicagounbound.uchicago.edu/uclf/iss1/8

Crossley, D. A. (2017). Finding Feminism: Millennial Activists and the Unfinished Gender Revolution. New York: New York University Press.

Davis, A. (1983). [1981] Women, Race, and Class Random House.

--"Rape Racism, and the Capitalist System" (1978). The Black Scholar (April): 24-30.

Elizabeth, J. (2017). "The Intersectionality of Believability." Ms. Magazine Blog. November 8.

Garber, Megan 2017 "Harvey Weinstein's Statements Have Taken a Striking Turn." The Atlantic (October 23). Retrieved from: https://www.theatlantic.com/entertainment/archive/2017/10/the-evolutionof-harvey-weinsteins-statements/543690/.

Garcia, S. (2017). "The Woman Who Created \#MeToo LongBefore Hashtags." New York Times (October 20). Rederived from: https://www.nytimes.com/2017/10/20/us/me- too- movement- taranaburke.html

Gill, R., \& Orgad, S. (2018). "The Amazing Bounce- Backable Woman: Resilience and the Psychological Turn in Neoliberalism." Sociological Research Online (March), 23(2), pp. 477-495.

Gieseler, C. (2019). The Voices of \#MeToo: From Grassroots Activism to a Viral Roar. London: Rowman and Littlefield.

Grady, A., \& Oxley, L. (2019). "\#NotAllWomen: Intersectionality and the \#MeToo movement." UTS Centre for Social Justice News and Articles. Retrieved from: https://www.uts.edu.au/partners-andcommunity/initiatives/social-justice-uts/news/notallwomen-intersectionality-and-metoo , 15 April.

Harris, D. (2019). Black Feminist Politics from Kennedy to Trump. London and New York: Routledge.

Hayek, S. ( 2017). "Harvey Weinstein Is My Monster." New York Times, December 12. Retrieved from: https://www.nytimes.com/interactive/2017/12/13/opinion/contributors/salma-hayek-harveyweinstein.html.

Hewitt, N. A. ed. (2010). No Permanent Waves: Recasting Histories of U.S. Feminism London and New York: Rutgers.

Hill Collins, P. (2000). [1990] Black Feminist Thought: Knowledge, Consciousness, and the Politics of Empowerment. New York: Routledge.

Hooks, B. (2015). Ain't I A Woman?Black Women and Feminism. New York: Routledge.

Hosterman, Alec .R. Naomi. R. Johnson, Ryan Stouffer, and Steven Herring. 2018 "Twitter, Social Support Messages and the \#MeToo Movement." The Journal of Social Media in Society (Fall), 7(2), pp. 69-91.

Johnson, C. (2018). "A Timeline of Events Related to the \#MeToo Movement." Chicago Tribune. March 16, 2018. Retrieved from: http://www.chicagotribune.com/lifestyles/ct-me-too-timeline-20171208htmlstory.html.

James, J. (1988). The Angela Davies Reader. Malden, MS: Blackwell.

Johnson, H. M., \& O’Neil, M. (2018). "Reframing Sexual Violence: From \#MeToo to Time's Up." Stanford Social Innovation Review, April 17. Retrieved from: https://ssir.org/articles/entry/reframing_sexual_violence_from_metoo_to_times_up.

Kaeh Garrison, E. (2000). "U.S. Feminism-Grrrl Style! Youth (Sub)Cultures and the Technologies of the Third Wave." Feminist Studies, 26(1), pp. 141-170.

Kantor, J., \& Twohey, M. (2017). "Harvey Weinstein Paid Off Sexual Harassment Accusers for Decades." New York Times Oct. 5. Retrieved from: http://www.nytimes .com /2017/10/05/us/harveyweinstein- harassment- allegations.html.

MacKinnon, C. A. (2019). "Where \#MeToo Came From, and Where It's Going The movement is moving the culture beneath the law of sexual abuse." The Atlantic March 24) Retrieved from: https://www.theatlantic.com/ideas/archive/2019/03/catharine-mackinnon-what-metoo-haschanged/585313/ 
McCartney, J. (2018). "Me! Me! \#MeToo! How Hollywood hijacked feminism." The Spectator 3 March. Retrieved from: https://www.spectator.co.uk/2018/03/me-me-metoo-how-hollywood-hijacked-feminism/

Mendes, K., Ringrose, J., \& Keller, J. (2018). "\#MeToo and the promise and pitfalls of challenging rape culture through digital feminist activism." European Journal of Women's Studies, 25(2), pp. 236246.

Milano, A. (2017). Twitter.com. Retrieved from: https://twitter.com/alyssa milano/status/919659438700670976?lang=en, posted on October $15^{\text {th }}$.

Moniuszko, S. M. (2017). "Harvey Weinstein responds to Salma Hayek calling him her 'monster'." December 13. Retrieved from: https://www.usatoday.com/story/life/people/2017/12/13/salma-hayekharvey-weinstein-my-monster-too/948605001/.

Nyong'o, L. (2017). "Lupita Nyong'o: Speaking Out About Harvey Weinstein." New York Times October 19. Retrieved from: https://www.nytimes.com/2017/10/19/opinion/lupita-nyongo-harveyweinstein.html

Ohlheseiser, A. (2017). "The woman behind 'Me Too' knew the power of the phrase when she created 10 years ago." The Washington Post October 19. Retrieved from: https://www.washingtonpost.com/news/the-intersect/wp/2017/10/19/the-woman-behind-me-too-knewthe-power-of-the-phrase-when-she-created-it-10-years-ago/.

Perez, L. (2018). "Laverne Cox Talks Intersectionality of \#Me Too Movement." Hollywood Reporter 2/8. Retrieved from: https://www.hollywoodreporter.com/news/laverne-cox-talks-intersectionality-metoomovement-1083108

Read, B. (2018). "\#MeToo Founder Tarana Burke: "Watch Carefully Who Are Called 'Leaders' of the Movement",'Vogue (February 22. Retrieved from: https://www.vogue.com/article/me-too-tarana-burkefrustrations-mainstream-twitter-thread).

Reger, J. (2012). Everywhere and Nowhere: Contemporary Feminism in the United States. Oxford: Oxford University Press.

Rentschler, C. A., \& Thrift, S. C. (2015). “Doing feminism: Event, archive, techne." Feminist Theory, 16(3); pp. 239-249.

Rodino-Colocino, M. (2018). "Me too, \#MeToo: Countering Cruelty with Empathy." Communication and Critical/Cultural Studies, 15(1), pp. 96-100, https://doi.org/10.1080/14791420.2018.1435083.

Saad, N. (2018). "Time's Up has its Oscars moment and touts diversity, inclusion and intersectionality." Los Angeles Times, March 4. Retrieved from:

http://www.chicagotribune.com/entertainment/envelope/ct-oscars-me-too-moment-20180304-story.html.

Scott, E. (2017). "The marginalized voices of the \# \#MeToo movement," The Washington Post. (December 7) the-marginalized-voices-of-the-metoomovement/?noredirect=on\&utm term=.f8e6f0315a24.

Shamus Jordan, K. (2018). "\#MeToo founder Tarana Burke to speak at Detroit conference" Detroit Free Press, April 23 Retrieved from: https://www.freep.com/story/news/2018/04/23/me-too-taranaburke-detroit/542024002/.

Thalusan, M. (2017). "How \#MeToo Stands to Marginalize Trans and Gender- Nonconforming People." Them 27 October. Retrieved from: https://www.them.us/story/how-metoo-stands-to-marginalize

Vagianos, A. (2017). "Me Too" Campaign Was Created By a Black Women 10 Years Ago, The Huffington Post (Oct. 17 1:44 PM). Retrieved from: http://www.huffington post.com/entry/the-me-toocampaign-was-created-by-a-black-woman-10-years-ago_us_59e61a7fe4b02a215b336fee [https://perma.cc/NZ7F-T8FS]

Wallace, Michele 1976 Black Macho and the Myth of the Superwoman. New York: Verso.

Wagmeister, E. (2018). “Tarana Burke on Hollywood, Time's Up, and \#MeToo Backlash.” Variety, April 10. Retrieved from: https://variety.com/2018/biz/news/tarana-burke-times-up-me-too-backlash$\underline{1202748822 /}$

Wang, A. B. (2017). "Harvey Weinstein, accused by dozens, specifically disputes Lupita Nyong'o's harassment claims." The Washington Post, October 21. Retrieved from: https://www.washingtonpost.com/news/arts-and-entertainment/wp/2017/10/21/harvey-weinstein accused-by-dozens-specifically-disputes-lupita-nyongos-harassment-claims/?noredirect=on

White, G.B. (2017). "The Glaring Blind Spot of the '\#MeToo' Movement." The Atlantic, November 22 Retrieved from: https://www.theatlantic.com/entertainment/archive/2017/11/the-glaring-blind-spot-of-theme-too-movement/546458/

Zacharek, S., Dockterman, E., \& Haley, SE. (2017). "Person of the Year 2017: The Silence Breakers." Time December 18. Rederived from: http://time.com/time-person-of-the-year-2017-silence-breakers/.

Zarkov, D., \& Davis, K. (2018). "Ambiguities and dilemmas around\# MeToo:\# ForHow Long and\# WhereTo?." European Journal of Women's Studies: pp. 3-9. 
i Statement given at Cornell University, at a lecture sponsored by a student organization on February 6 , 2018.

"While the movement has opened the dialogue to "a vaster spectrum of survivors" (https://metoomvmt.org/about/\#history), the hashtag has raised criticism regarding its low appeal to intergenerational, trans, and non-binary communities (Grady 2019; Thalusan 2017)

iii Burke has used the expression "empowerment through empathy" in public lectures, media appearances, and interviews. See some instances in the media section of the organization's webpage (https://metoomvmt.org/media/ and Facebook page (https://www.facebook.com/events/uaf-schaibleauditorium/tarana-burke-metoo-empowerment-through-empathy/224625778098846/).

iv Among the scholars criticizing this type of empathy Rodino-Colocino mentions Megan Boler, Sarah Ahmed, and bell hooks (Rodino-Colocino, 2018: 96).

${ }^{v}$ Milano was even allegedly unaware of the origin of the expression. It was only after some journalists and activists who knew Burke's work - including, among other, the feminist journalist Britni Danielle, the founder of the movement Black Lives Matter Alicia Garza, and the Latina blogger Aura Bogado - denounced the overlook on Twitter that the media set the record straight. On October $19^{\text {th }}$, The Washington Post published an article that acknowledged Burke as the initiator of the movement, also quoting Burke's declarations about the hashtag (Ohlheseiser 2017). In the following days and weeks, Burke's role as the founder of \#Me Too was widely publicized and Burke began participating in the campaign on behalf of the hashtag (Garcia 2017; Johnson, 2018; Ohlheiser, 2017). About these Tweets, see, among other, Gieseler, 2019 and Vagianos 2017.

vi The people behind McDormand's otherwise mysterious hint to the "inclusion rider" are Stacy Smith, professor of Film Studies at Santa Barbara University, and Kalpana Kotagal, a partner and a member of the civil rights \& employment practice group Cohen Milstein and Chair of the firm's Hiring and Diversity Committee (Martin Belam and Sam Levina).

vii The title of hooks' collection is a quotation from a plight that Anna Cooper gave to the 1893 World Congress of Representative Women, in which the African American activist denounced US racist culture across gender and class lines (2015:2). As hooks explains, Cooper was the first among a group of Black women "that broke through the long years of silence and began to articulate and record their experiences" ( (ibid).

viii While maintaining race at the centre of Black Feminist politics, she claims that other affiliated disciplines have influenced Black Feminism, such as Harris lists African-American Studies, Asian American Studies, Chicano/Latino Studies, Native American and Indigenous Studies, Women's and Gender Studies, Queer Studies, critical race theory, cultural studies, and transnational, postcolonial and diaspora studies, as well as recent radical movements such as, for instance, Black Lives Matter (2019: 6).

${ }^{i x}$ Ferree, Myra Marxx. Inequality, intersectionality, and the politics of discourse,"

${ }^{x}$ As explained on the me too.'s website, the nonprofit benefit corporation GGE "receives tax-deductible charitable contributions for the benefit and use of implementing the 'me too.' movement's programming" (https://metoomvmt.org/about/\#history).

xi Some of me too.'s activities are documented on the organization's website, at the sections "media" and "press" (https://metoomvmt.org/media/;https://metoomvmt.org/category/in-the-press/).

xii https://metoomvmt.org/hbcutour/

xiii On the same topic, Chamberlain also published the article "Affective temporality: towards a fourth wave." Gender and Education. Vol.. 28, No. 3 (2016): 458-464, http://dx.doi.org/10.1080/09540253.2016.1169249.

xiv While downplaying chronological and generational distinction, Chamberlain's discussion of Fourth Wave feminism still maintains historical continuity and geo-cultural periodization. Nancy A. Hewitt, in No Permanent Waves: Recasting Histories of U.S. Feminism, criticizes this reading of "wave feminism" because of its traditional approach to spatio-temporal co-ordinates (2010). Against this approach, she proposes " a wave model" based on the "messy multiplicity of feminist activism across U.S history and beyond its border" (Hewitt, 2010: 7).

xv Some of the case studies considered include SlutWalk, Black Lives Matter, The Women's Room and Everyday Sexism (ibid). 